\title{
Anti-inflammatory Strategies for Schizophrenia: A Review of Evidence for Therapeutic Applications and Drug Repurposing
}

\author{
Jonghee Hong ${ }^{1}$, Minji Bang ${ }^{2}$ \\ ${ }^{1} \mathrm{CHA}$ University School of Medicine, ${ }^{2}$ Department of Psychiatry, CHA Bundang Medical Center, CHA University School of Medicine, Seongnam, \\ Korea
}

\begin{abstract}
Schizophrenia is a debilitating psychiatric disorder with a substantial socioeconomic and humanistic burden. Currently available treatment strategies mostly rely on antipsychotic drugs, which block dopaminergic effects in the mesolimbic pathway of the brain. Although antipsychotic drugs help relieve psychotic symptoms, a definitive cure for schizophrenia has yet to be achieved. Recent advances in neuroinflammation research suggest that proinflammatory processes in the brain could cause alterations in neurobehavioral development and increase vulnerability to schizophrenia. With a growing need for novel strategies in the treatment of schizophrenia, it would be meaningful to review the current evidence supporting the therapeutic potential of anti-inflammatory strategies. This review details the key findings of clinical trials that investigate the efficacy of anti-inflammatory agents as adjuvants to antipsychotic treatment. We further discuss the possibilities of repurposing anti-inflammatory agents and developing novel strategies for the treatment of schizophrenia.
\end{abstract}

KEY WORDS: Schizophrenia; Inflammation; Anti-inflammatory agents; Drug repositioning.

\section{INTRODUCTION}

Schizophrenia is a debilitating psychiatric disorder with a substantial socioeconomic and humanistic burden not only on the affected individuals but also on the caregivers $[1,2]$. Since the proposal of the dopamine hypothesis, aberrations in the central dopaminergic system have been considered as a core pathophysiological mechanism of schizophrenia [3,4]. Currently used antipsychotic drugs (APDs), which reduce mesolimbic dopamine transmission by blocking postsynaptic D2 receptors, influence the clinical remission of psychotic symptoms in patients with schizophrenia [5]. However, the effect is modest and there is still a long way to go before a definitive cure for schizophrenia is achieved. Moreover, the long-term administration of APDs causes considerable side effects, including extrapyramidal symptoms, metabolic dysregula-

Received: May 15, 2019 / Revised: September 12, 2019

Accepted: November 4, 2019

Address for correspondence: Minji Bang

Department of Psychiatry, CHA Bundang Medical Center, 59

Yatap-ro, Bundang-gu, Seongnam 13496, Korea

E-mail: minjibang@cha.ac.kr

ORCID: https://orcid.org/0000-0002-1669-4014 tions, and tardive dyskinesia [6,7]. Accordingly, there has been an increasing need for the development of novel therapeutic strategies to treat schizophrenia.

On the basis of the existing evidence that inflammation is fundamentally involved in the development and progression of schizophrenia, we aimed to review the up-todate evidence supporting the therapeutic potential of anti-inflammatory agents in patients with schizophrenia. Recent clinical trials of anti-inflammatory agents as an adjuvant to antipsychotic drugs have shown some positive results, suggesting that the regulation of inflammatory processes may be therapeutically beneficial. This review provides meaningful insights into repurposing anti-inflammatory agents and developing novel strategies for the treatment of schizophrenia.

\section{IMMUNE DYSREGULATION IN THE PATHOGENESIS OF SCHIZOPHRENIA}

A body of epidemiological studies suggests that maternal immune activation (MIA) induced by prenatal infection is closely associated with an increased risk for developing schizophrenia in offspring $[8,9]$. Preclinical

(ㄷ) This is an Open-Access article distributed under the terms of the Creative Commons Attribution Non-Commercial License (http://creativecommons.org/licenses/by-nc/4.0) which permits unrestricted non-commercial use, distribution, and reproduction in any medium, provided the original work is properly cited. 
studies using non-human MIA models have provided yet more compelling evidence that MIA increases vulnerability to schizophrenia by causing acute and long-lasting alterations in fetal neurobehavioral development $[10,11]$. Deficits in prepulse inhibition and latent inhibition, the well-known behavioral phenotypes in animal models of schizophrenia [12], have been consistently observed in rodent offspring of MIA mothers [13-16]. Moreover, morphological and neurochemical alterations in the central nervous system (CNS) that confer susceptibility to schizophrenia have been shown at early and late postnatal ages in response to prenatal MIA [17-21].

The detrimental effects of MIA on the fetal brain are considered to be mediated by the elevated release of pro-inflammatory cytokines, including interleukin (IL)-1 $\beta$, IL-6, and tumor necrosis factor (TNF)- $\alpha$, in the fetal environment [22-24]. Increased expression of pro-inflammatory cytokines is reportedly found in the fetal brain of rats following maternal administration of endotoxins, such as lipopolysaccharide and polyinosinic:polycytidylic acid (poly I:C) [25-28]. In particular, IL-6 has been suggested as a critical mediator of neuroinflammation that alters the fetal neurodevelopmental process and causes structural and functional deficits in the brain $[29,30]$.

In accordance with the findings from animal studies, elevated pro-inflammatory cytokines during pregnancy were found to be associated with an increased risk for schizophrenia [31-33]. Patients with schizophrenia with a history of prenatal exposure to infection showed impaired neurocognitive performance [34-36] and structural abnormalities in the brain $[37,38]$. Thus, immune dysregulation may fundamentally contribute to the pathogenesis of schizophrenia, even before the onset of fullblown psychosis.

\section{INFLAMMATORY MECHANISMS IN THE SCHIZOPHRENIC BRAIN}

Recent studies revealed that pro-inflammatory cytokines, including IL-1 $\beta$, IL-6, and TNF- $\alpha$, were increased in the peripheral blood of patients with schizophrenia during acute psychotic exacerbations, suggesting that immunological alterations may affect the clinical status after the onset of illness $[39,40]$. Cytokines are also released from microglia, the innate immune cells residing in the CNS, in response to injury, infection, and stressful life events [41]. The inflammatory reactions in the CNS can be conditioned to certain stimuli and promoted by a 'priming' or kindling mechanism of the immune system, particularly via perinatal activation of microglia [42-45]. The release of pro-inflammatory cytokines from primed microglia is exaggerated by conditioned stimuli, for example, prior infections and environmental stress $[46,47]$. This process confers intrinsic susceptibility to external stressors during adolescence, leading to brain damages to stress-sensitive regions, including the prefrontal cortex and hippocampus [48]. Previous animal studies showed that administration of IL-6 to mice produced sensitization to neurobiological insults by amphetamine $[49,50]$ or ketamine [51], suggesting an intertwined interaction of pro-inflammatory cytokines with the dopaminergic and glutaminergic neurotransmitter systems.

Activated microglia themselves also play a critical role in inflammation-induced brain damage by shifting kynurenine metabolism toward the production of quinolinic acid (QA), which causes oxidative stress and excitatory neurotoxicity [52-54]. The high concentration of QA was found to disrupt the neurodevelopmental process and cause cognitive and behavioral alterations relevant to schizophrenia in animal studies $[55,56]$. Although it remains to be further elucidated how kynurenine metabolites are implicated in schizophrenia, sustained microglial activation may cause further neurodegeneration and deterioration of illness [41,57]. The involvement of activated microglia is supported by previous studies that showed an increased density of microglia in postmortem brain analysis of patients with chronic schizophrenia [58,59]. In vivo neuroimaging studies using positron emission tomography also provided supportive evidence for the presence of activated microglia in the gray matter of patients with schizophrenia $[60,61]$ and individuals at ultra-high risk for psychosis [62].

Taken together, the possible roles of immune-activated microglia and inflammation throughout the disease course of schizophrenia indicates that developing anti-inflammatory strategies would be a promising avenue to optimize the treatment for schizophrenia (Fig. 1) [63]. Next, we review preclinical and clinical studies that investigate the efficacy of anti-inflammatory agents as an adjuvant to antipsychotic medications. 


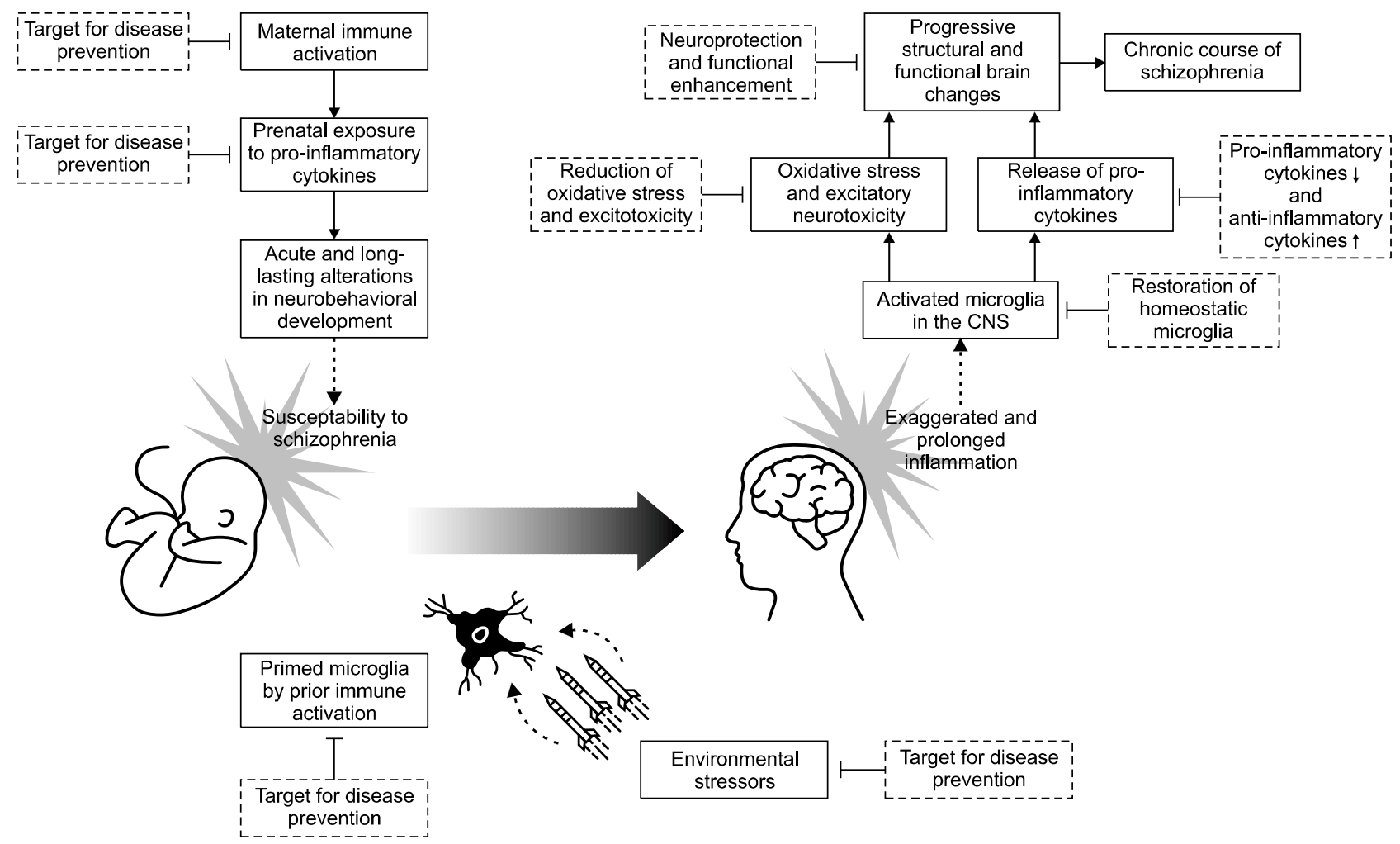

Fig. 1. The role of inflammation and the immune system in schizophrenia and potential targets for the treatment of schizophrenia. Currently used anti-inflammatory drugs, such as aspirin and celecoxib, inhibit the cyclooxygenase pathway of inflammation at the systemic level. Several drugs, originally indicated for the treatment of medical diseases, appear promising for the treatment of schizophrenia owing to their anti-inflammatory property (e.g., minocycline, statins). In addition, omega-3 fatty acids and neurosteroids can reduce oxidative stress and enhance neuronal repair. Davunetide, derived from the activity-dependent neuroprotective protein, promotes neuronal stability and repair. Biological agents, including monoclonal antibodies, target specific pro-inflammatory cytokines and modulate the inflammatory process. Recently, the immune modulatory property of mesenchymal stem cells has received much attention for potential therapeutic application in psychiatry. Mesenchymal stem cells have an ability to change the functional phenotype of microglia from an activated to an anti-inflammatory state. Although future investigation will be required to establish effective and safe treatment strategies, these anti-inflammatory agents may be applied before the onset of schizophrenia.

\section{PRECLINICAL STUDIES OF THE THERAPEUTIC EFFECTS OF ANTI-INFLAMMATORY AGENTS ON SCHIZOPHRENIA}

Preclinical studies have provided evidence for a potential therapeutic role of anti-inflammatory agents in the treatment of schizophrenia; however, the reliability of behavioral alterations induced by psychomimetic drugs in animal models is limited compared with psychotic symptoms manifested in humans. El-Sayed El-Sisi et al. [64] showed a significant therapeutic effect of celecoxib, a well-known anti-inflammatory agent that selectively inhibits cyclooxygenase (COX)-2, using the amphetamine-induced model in rats [64]. Combined administration of celecoxib with risperidone reversed behavioral impairments induced by amphetamine and reduced
TNF- $\alpha$ levels in the rat brain. Brenhouse and Andersen [65] revealed that prophylactic COX-2 inhibition prevented the loss of parvalbumin (PV), a calcium-binding protein expressed in a specific type of $\gamma$-aminobutyric acid (GABA)-ergic cells [66], in male rats with early-life stress exposure. Given that impaired functioning of PV-expressing GABAergic neurons is closely associated with the pathogenesis of schizophrenia $[67,68]$, previous results may imply that the suppression of neuroinflammation has the potential to restore neuronal alterations relevant to schizophrenia.

\section{LITERATURE SELECTION CRITERIA FOR CLINICAL TRIALS}

We selected eligible articles according to the Preferred Reporting Items for Systematic Reviews and Meta-Analyses 
(PRISMA) statement [69]. The systematic search was conducted until August 2019 using electronic databases (EBSCO Discovery Service, MEDLINE Complete, and PubMed). The following terms were used to identify relevant studies: (aspirin or celecoxib or n-acetylcysteine or minocycline or statin or omega-3 or davunetide or erythropoietin or pregnenolone or estrogen or selective estrogen receptor modulators [SERMs] or raloxifene or biologics or interferon or mesenchymal stem cell or monoclonal antibody) and (schizophrenia or psychosis or antipsychotics). In the next step, we manually searched for additional relevant articles.

We defined our literature selection criteria as follows: (1) randomized controlled trials (RCTs), case-controlled studies, pilot studies, and meta-analyses comprising patients with schizophrenia spectrum disorders; (2) studies including administration of anti-inflammatory drugs with antipsychotics to patients; (3) if the total number of clinical trials regarding certain drugs was above five, we selected the corresponding meta-analyses instead; (4) for meta-analyses, we selected those that included as many studies or as much information as possible; and (5) written in English. Seventeen studies were finally included in this review (Fig. 2).

\section{CLINICAL EVIDENCE FOR THE THERAPEUTIC EFFECTS OF ANTI-INFLAMMATORY AGENTS ON SCHIZOPHRENIA}

Table 1 summarizes the results of clinical trials that have investigated the therapeutic effects of anti-inflammatory agents used as adjuvants to antipsychotic treatment in patients with schizophrenia. The current findings of those trials suggest that adjuvant anti-inflammatory strategies may be beneficial by relieving clinical symptoms in patients with schizophrenia. Drug repurposing, which is the application of existing therapeutics for a novel disease indication [70], is a promising approach to overcome limitations of current antipsychotic medications targeting dopaminergic pathways.

\section{Aspirin}

Aspirin is one of the most commonly used anti-inflammatory drugs that inhibits the COX enzymes. Laan et al. [71] conducted a randomized, double-blind, placebo-controlled study to determine the efficacy of aspirin adjuvant therapy. Patients were administered aspirin $(1,000 \mathrm{mg} /$ day $)$ or a placebo as adjuvant therapy to antipsychotics for 3 months. The adjuvant therapy significantly reduced the positive subscale and total scores of the Positive and Negative Syndrome Scale (PANSS) but did not improve cognition. A recent aspirin study con-

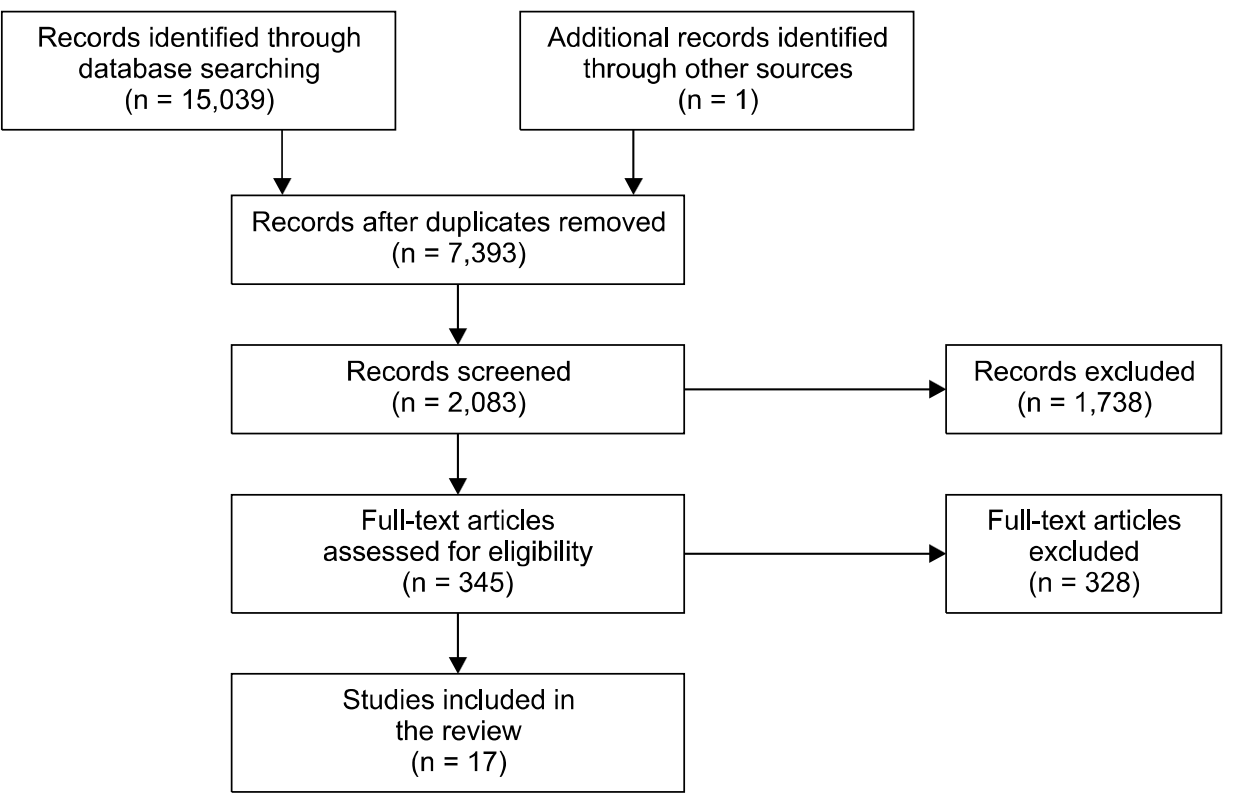

Fig. 2. Flowchart of the literature selection procedure. 
Table 1. Clinical trials using anti-inflammatory agents combined with antipsychotic treatment and their therapeutic effects on clinical symptoms in patients with schizophrenia

\begin{tabular}{|c|c|c|c|}
\hline Author & Number & Dosing and duration & Results \\
\hline \multicolumn{4}{|l|}{ Aspirin (ASP) } \\
\hline Attari et al. [72] & $\begin{array}{l}60 \text { SSD: } 20 \text { ASP } \\
\quad(325 \mathrm{mg})+\text { APD; } 20 \\
\text { ASP }(500 \mathrm{mg})+ \\
\text { APD; } 20 \text { PL + APD }\end{array}$ & $\begin{array}{l}\text { ASP } 325 \text { or } 500 \mathrm{mg} / \text { day; } \\
\quad 6 \text { weeks }\end{array}$ & $\begin{array}{l}\text { - The positive, negative, and general psychopathology scores of } \\
\text { the PANSS were more reduced in the aspirin groups than in the } \\
\text { placebo group. } \\
\text { - Omeprazole ( } 20 \mathrm{mg} / \text { day) was given to all patients to reduce } \\
\text { gastrointestinal complications. } \\
\text { - There were no significant side effects. }\end{array}$ \\
\hline Laan et al. [71] & $\begin{array}{l}70 \text { SCZ: } 33 \text { ASP + } \\
\text { APD; } 37 \mathrm{PL}+\text { APD }\end{array}$ & $\begin{array}{l}\text { ASP } 1,000 \mathrm{mg} / \text { day; } \\
3 \text { months }\end{array}$ & $\begin{array}{l}\text { - The total PANSS scores were improved. } \\
\text { - Pantoprazole ( } 40 \mathrm{mg} / \text { day) was given to all patients for gastric } \\
\text { protection. } \\
\text { - There were no significant side effects. }\end{array}$ \\
\hline \multicolumn{4}{|l|}{ Celecoxib (CEL) } \\
\hline $\begin{array}{l}\text { Akhondzadeh } \\
\text { et al. [74] }\end{array}$ & $\begin{array}{l}60 \text { SCZ: } 30 \text { CEL + RIS; } \\
\quad 30 \text { PL + RIS }\end{array}$ & $\begin{array}{l}\text { CEL } 400 \text { mg/day; RIS } \\
6 \text { mg/day; } 8 \text { weeks }\end{array}$ & $\begin{array}{l}\text { - The treatment significantly reduced the PANSS positive and total } \\
\text { scores. } \\
\text { - No significant benefit for negative symptoms. } \\
\text { - There were no significant side effects. }\end{array}$ \\
\hline Müller et al. [73] & $\begin{array}{l}50 \text { SCZ: } 25 \text { CEL + RIS; } \\
\quad 25 \text { PL + RIS }\end{array}$ & $\begin{array}{l}\text { CEL } 400 \mathrm{mg} / \text { day; RIS } \\
\quad 2-6 \mathrm{mg} / \text { day; } 5 \text { weeks }\end{array}$ & $\begin{array}{l}\text { - None of the positive and negative symptom scores of the PANSS } \\
\text { showed significant improvement. } \\
\text { - The total PANSS scores were reduced. } \\
\text { - The cognitive items 'difficulty in abstract thinking' and } \\
\text { 'conceptual disorganization' were improved. } \\
\text { - There were no significant side effects in the treatment group. }\end{array}$ \\
\hline Müller et al. [76] & $\begin{array}{l}50 \text { SCZ: } 25 \text { CEL + AMl; } \\
25 \text { PL + AMl }\end{array}$ & $\begin{array}{l}\text { CEL } 400 \text { mg/day; } \\
\text { AMI } 200-1,000 \\
\text { mg/day; } \\
6 \text { weeks }\end{array}$ & $\begin{array}{l}\text { - The negative symptom scores of the PANSS were reduced. } \\
\text { - There were no significant side effects. }\end{array}$ \\
\hline $\begin{array}{l}\text { Rapaport } \\
\text { et al. [75] }\end{array}$ & $\begin{array}{l}35 \text { SCZ: 18 CEL + APD; } \\
17 \text { PL + APD }\end{array}$ & CEL 400 mg/day; 8 weeks & $\begin{array}{l}\text { - The treatment cohorts did not differ on any of the clinical } \\
\text { outcome measures. } \\
\text { - There were no significant side effects. }\end{array}$ \\
\hline \multicolumn{4}{|c|}{$\mathrm{N}$-acetylcysteine (NAC) } \\
\hline Berk et al. [85] & $\begin{array}{l}140 \text { SCZ: } 69 \text { NAC + } \\
\text { APD; } 71 \text { PL + APD }\end{array}$ & NAC 2 g/day; 24 weeks & $\begin{array}{l}\text { - The total, negative, and general psychopathology scores of } \\
\text { PANSS were reduced. } \\
\text { - Positive symptoms were not significantly improved. } \\
\text { - The CGI-severity, CGl-improvement scores were improved. } \\
\text { - There were no significant side effects. }\end{array}$ \\
\hline $\begin{array}{l}\text { Farokhnia } \\
\text { et al. [81] }\end{array}$ & $\begin{array}{l}42 \text { SCZ: } 21 \text { NAC + RIS; } \\
21 \text { PL + RIS }\end{array}$ & $\begin{array}{l}\text { NAC } 2 \mathrm{~g} / \text { day; RIS } \\
\quad 6 \mathrm{mg} / \text { day; } 8 \text { weeks }\end{array}$ & $\begin{array}{l}\text { - The negative symptom scores of the PANSS were significantly } \\
\text { improved. } \\
\text { - There were no significant side effects. }\end{array}$ \\
\hline \multicolumn{4}{|l|}{ Minocycline (MIN) } \\
\hline Xiang et al. [87] & $\begin{array}{l}548 \text { SSD: } 286 \mathrm{MIN}+ \\
\text { APD; } 262 \mathrm{PL}+\text { APD }\end{array}$ & $\begin{array}{l}\text { MIN } 171.9 \pm 31.2 \mathrm{mg} / \text { day; } \\
\quad 18.5 \pm 13.4 \text { weeks }\end{array}$ & $\begin{array}{l}\text { - } 8 \text { trials } \\
\text { - The total, positive, negative, and general psychopathology } \\
\text { scores of the PANSS and BPRS were improved. } \\
\text { - There was no significant improvement in cognitive function. } \\
\text { - No significant differences in adverse events were found between } \\
\text { the adjuvant therapy group and the placebo group. }\end{array}$ \\
\hline \multicolumn{4}{|l|}{ Statins (STAs) } \\
\hline Shen et al. [97] & $\begin{array}{l}339 \text { SCZ: } 169 \text { STA + } \\
\text { APD; } 170 \text { PL + APD }\end{array}$ & $\begin{array}{l}\text { Pravastatin } 40 \mathrm{mg} / \text { day; } \\
\text { lovastatin } 20 \mathrm{mg} / \text { day; } \\
\text { simvastatin } 40 \mathrm{mg} / \text { day; } \\
\text { atorvastatin } 20 \mathrm{mg} / \text { day; } \\
6 \text { weeks }-6 \text { months }\end{array}$ & $\begin{array}{l}\text { - } 6 \text { trials } \\
\text { - The positive and negative symptom scores of the PANSS were } \\
\text { decreased. } \\
\text { - There was a correlation with simvastatin adjunctive therapy and } \\
\text { the reduction in negative symptoms. }\end{array}$ \\
\hline
\end{tabular}


Table 1. Continued

\begin{tabular}{|c|c|c|c|}
\hline Author & Number & Dosing and duration & Results \\
\hline \multicolumn{4}{|l|}{ Other agents } \\
\hline \multirow[t]{4}{*}{ Cho et al. [101] } & 816 SSD & $\begin{array}{l}\text { EPA; DHA; EPA + } \\
\quad \text { DHA + oleic acid; } \\
\quad 4-26 \text { weeks }\end{array}$ & $\begin{array}{l}\text { - } 20 \text { trials } \\
\text { - The total, positive, and negative symptom scores of the PANSS } \\
\text { were not significantly reduced. } \\
\text { - Cognitive function was not significantly improved. }\end{array}$ \\
\hline & $\begin{array}{l}264 \text { SSD: } 135 \text { PRG + } \\
\text { APD; } 129 \text { PL + APD }\end{array}$ & $\begin{array}{l}\text { PRG } 0.03-0.5 \\
\text { g/day; } \\
\quad 8 \text { weeks }\end{array}$ & $\begin{array}{l}\text { - } 5 \text { trials } \\
\text { - The total PANSS scores were decreased, but positive and negative } \\
\text { symptoms were not significantly improved in } 4 \text { trials. } \\
\text { - Cognitive function was significantly improved. }\end{array}$ \\
\hline & 492 SSD & $\begin{array}{l}\text { ESR } 0.2-2 \mathrm{mg} / \text { day; } \\
\quad 2-8 \text { weeks }\end{array}$ & $\begin{array}{l}\text { - } 8 \text { trials } \\
\text { - The total, positive, and negative symptom scores of the PANSS } \\
\text { were decreased. }\end{array}$ \\
\hline & $\begin{array}{l}583 \text { SSD: } 297 \\
\text { SERMs + APD; } \\
286 \text { PL + APD }\end{array}$ & $\begin{array}{l}\text { Raloxifene } 60 \text { or } 120 \\
\text { mg/day; } 6-24 \\
\text { weeks }\end{array}$ & $\begin{array}{l}\text { - } 9 \text { trials } \\
\text { - The total and positive symptom scores of the PANSS were } \\
\text { decreased. }\end{array}$ \\
\hline $\begin{array}{l}\text { Ehrenreich } \\
\text { et al. [105] }\end{array}$ & $\begin{array}{l}39 \text { SCZ: } 20 \text { EPO + APD; } \\
19 \text { PL + APD }\end{array}$ & $\begin{array}{l}\text { EPO } 40,000 \\
\text { IU/week for } \\
3 \text { months; } 2 \text { years }\end{array}$ & $\begin{array}{l}\text { - Cognitive function was improved. } \\
\text { - There were no benefits for the PANSS and social functioning. } \\
\text { - There were no significant side effects. }\end{array}$ \\
\hline Javitt et al. [102] & $\begin{array}{l}63 \text { SCZ: } 20 \text { DAV }(5 \mathrm{mg})+ \\
\text { APD; } 21 \text { DAV (30 mg) } \\
\text { + APD; } 22 \mathrm{PL}+\text { APD }\end{array}$ & $\begin{array}{l}\text { DAV } 5 \text { or } 30 \mathrm{mg} / \text { day; } \\
12 \text { weeks }\end{array}$ & $\begin{array}{l}\text { - There were no significant benefits for cognitive function measured } \\
\text { using the MCCB and SCoRS. } \\
\text { - The UPSA-measured everyday functioning was improved. } \\
\text { - There were no significant side effects. }\end{array}$ \\
\hline
\end{tabular}

SSD, schizophrenia spectrum disorders; APD, antipsychotic drugs; PL, placebo; PANSS, positive and negative syndrome scale; SCZ, schizophrenia; RIS, risperidone; AMI, amisulpride; CGI, clinical global impression scale; BPRS, brief psychiatric rating scales; EPA, eicosapentaenoic acid; DHA, docosahexaenoic acid; PRG, pregnenolone; ESR, estrogens; SERM, selective estrogen receptor modulators; EPO, erythropoietin; DAV, davunetide; MCCB, matrics consensus cognitive battery; SCoRS, schizophrenia cognition rating scale; UPSA, ucsd performance-based skills assessment.

ducted by Attari et al. [72] showed significant improvement in positive, negative, and general psychopathology of patients with schizophrenia who received lower doses of aspirin (325 or $500 \mathrm{mg}$ ) daily for 6 weeks. Since regular use of aspirin increases the risk of gastrointestinal bleeding in a dose-dependent manner, more research is needed to determine appropriate doses that minimize side effects for anti-inflammatory treatment strategies in schizophrenia.

\section{Celecoxib}

Celecoxib, a well-known selective COX-2 inhibitor, also has been suggested to have antipsychotic potential, although the findings remain controversial. Several clinical trials were conducted to assess the efficacy of celecoxib adjuvant therapy. Müller et al. [73] gave celecoxib (400 $\mathrm{mg} /$ day) to patients with schizophrenia for 5 weeks and reported a significant improvement in the total PANSS score along with an improvement in cognition, contrarily to the results of the aspirin study by Laan et al. [71] In a similar trial, Akhondzadeh et al. [74] reported that celecoxib (400 mg/day) combined with risperidone $(6$ $\mathrm{mg} /$ day) administered to patients with chronic schizo- phrenia for 8 weeks was superior to risperidone alone on the positive subscale and total scores of the PANSS. In contrast, Rapaport et al. [75] reported that the outcomes of celecoxib ( $400 \mathrm{mg} /$ day) with antipsychotics for 8 weeks did not differ from the outcomes of placebo with antipsychotics for continuously symptomatic patients with schizophrenia. Recently, Müller et al. [76] conducted celecoxib (400 mg/day) adjuvant treatment with amisulpride $(200-1,000 \mathrm{mg} /$ day $)$ for early-stage patients with schizophrenia. This study showed a significant improvement of the negative subscale scores of the PANSS, but no significant effects on the other PANSS subscale scores.

\section{$\mathrm{N}$-acetylcysteine}

$\mathrm{N}$-acetylcysteine (NAC) has both an anti-inflammatory property, which leads to the reduction of proinflammatory cytokines $[77,78]$, and a well-known antioxidant property. Several studies have demonstrated that NAC regulated impaired glutamate and dopamine neurotransmission [79,80]. Farokhnia et al. [81] administered NAC (2 g/day) adjuvant treatment with risperidone (6 $\mathrm{mg} /$ day) to patients with chronic schizophrenia for 8 
weeks. In this study, the total PANSS scores and negative subscale scores decreased significantly, but there were no significant differences in the positive subscale scores.

Other properties can also be helpful in alleviating schizophrenia symptoms. NAC is a direct precursor of glutathione, which protects cells against the effects of reactive oxygen species [82]. Decreased glutathione levels in the brain lead to hypofunction of $\mathrm{N}$-methyl-D-aspartate (NMDA) receptors, suggesting that glutathione dysregulation contributes to the development of clinical symptoms of schizophrenia [83]. NAC administration can increase glutathione levels, which are decreased in schizophrenia, and potentiate the NMDA receptor response to glutamate [84]. Berk et al. [85] conducted a trial to investigate the potential of NAC to increase brain glutathione levels that are decreased in schizophrenia. In this trial, the total, negative, and general scores of the PANSS were significantly improved in the NAC group, but not positive scores. Further studies are required to understand the therapeutic role of NAC in the treatment of schizophrenia.

\section{Minocycline}

Minocycline is a tetracycline antibiotic. The effects of minocycline on schizophrenia are considered to be due to anti-inflammatory, neuroprotective properties, and inhibition of cytochrome P450 enzymes that metabolize antipsychotics such as clozapine [86]. Several studies on adjunctive minocycline for schizophrenia have been conducted. A meta-analysis [87] of 8 RCTs showed this therapy was superior to placebo. The PANSS and Brief Psychiatric Rating Scale scores of total, positive, negative, and general symptoms were improved, but there was no significant improvement of cognitive function. Although there were some adverse drug reactions like weight gain and dizziness in the individual studies, the meta-analysis found no significant differences between the minocycline group and the placebo group.

\section{Statins}

Statins are cholesterol-lowering agents that act by inhibiting 3-hydroxy-3-methylglutaryl coenzyme A reductase. Several studies suggested that statins have anti-inflammatory properties, with lowering proinflammatory markers such as IL-1 $\beta$, IL-6, TNF- $\alpha$, and C-reactive protein (CRP) levels [88-91]. Animal research showed that simvastatin promoted hyperlocomotion and alleviated anxi- ety-like behavior by up-regulation of NMDA receptors [92] . In addition, simvastatin also could alleviate cognitive function and had antipsychotic-like effects by modulating muscarinic receptors $\mathrm{M} 1 / 4$, central dopamine receptors D1/2, and the serotonin transporter [93-96]. A meta-analysis [97] of statin adjunctive therapy for schizophrenia showed statins improved the positive and negative symptom scores of the PANSS in 6 RCTs comprising 339 patients. Especially, only in the simvastatin group ( $40 \mathrm{mg} /$ day), there was a correlation between statin adjunctive therapy and the reduction in negative symptoms.

\section{Omega-3 fatty acids}

The effects of omega- 3 fatty acids on psychiatric disorders have also been examined widely. The typical properties of omega-3 fatty acids are anti-oxidation, anti-inflammation, and neuroprotection $[98,99]$. They are also essential for many biological activities including neurotransmission associated with psychiatric disorders [100]. However, Cho et al. [101] reported that there was no significant benefit of omega-3 adjunctive schizophrenia therapy in the 20 trials from 2001 to 2017 investigating the effects of omega-3. From a duration of 4 to 26 weeks, 816 schizophrenia spectrum patients participated and were administered placebo or eicosapentaenoic acid (EPA) in 11 trials, docosahexaenoic acid (DHA) in 1 trial and a mixture of EPA, DHA, and oleic acid in 6 trials. However, there were no significant improvements in the total, positive, and negative PANSS scores of patients or in their cognitive function.

\section{Other agents}

Several trials have been conducted to investigate the repurposing potential of various agents with neuroprotective properties. Javitt et al. [102] conducted a trial with 22 schizophrenia patients using davunetide, an eight-amino acid peptide derived from activity-dependent neuroprotective protein [103]. However, davunetide showed no benefit for schizophrenia. Erythropoietin (EPO) is widely used for treating anemia. Several studies reported neuroprotective effects of EPO, such as anti-apoptotic, anti-oxidative, and neurotrophic properties [104]. Ehrenreich et al. [105] conducted a trial with patients with chronic schizophrenia presenting with a cognitive deficit. They reported that weekly administration of 40,000 IU recombinant human EPO for 3 months was effective for 
Table 2. Clinical trials using biological agents combined with antipsychotic treatment and their therapeutic effects on clinical symptoms in patients with schizophrenia

\begin{tabular}{|c|c|c|c|}
\hline Author & Number & Dosing and duration & Results \\
\hline \multicolumn{4}{|c|}{ Interferon- $\gamma-1 \mathrm{~b}(\mathrm{IFN}-\gamma-1 \mathrm{~b})$} \\
\hline Grüber et al. [115] & $2 \mathrm{SCZ}$ & $\begin{array}{l}\text { INF- } \gamma-1 \mathrm{~b} 1.5 \mathrm{ml} / \text { week; } \\
\quad 4 \text { weeks }\end{array}$ & - The total PANSS scores were decreased. \\
\hline \multicolumn{4}{|l|}{ Monoclonal antibody } \\
\hline Girgis et al. [117] & $\begin{array}{l}36 \text { SCZ: } \\
19 \text { TOC + APD; } 17 \mathrm{PL}+ \\
\text { APD }\end{array}$ & $\begin{array}{l}\text { TOC } 8 \mathrm{mg} / \mathrm{kg} \text {, } \\
3 \text { infusions per month } \\
\text { (as necessarily dose } \\
\text { decreased for } \\
\text { tolerability); } 12 \text { weeks }\end{array}$ & $\begin{array}{l}\text { - The negative symptom scores of the PANSS were } \\
\text { significantly improved. } \\
\text { - No significant changes in behavioral outcomes }\end{array}$ \\
\hline Miller et al. [116] & $6 \mathrm{SCZ}$ & $\begin{array}{l}\text { TOC } 4 \mathrm{mg} / \mathrm{kg}, 2 \text { infusions } \\
\quad(0,4 \text { weeks }) ; 8 \text { weeks }\end{array}$ & $\begin{array}{l}\text { - No significant changes were observed. } \\
\text { - Verbal fluency performance was improved. }\end{array}$ \\
\hline Weickert et al. [118] & $\begin{array}{l}27 \text { SCZ + SZA: CNK + } \\
\text { APD; PL + APD } \\
\text { (The number of patients } \\
\text { in each group is not } \\
\text { presented) }\end{array}$ & $\begin{array}{l}\text { CNK } 150 \text { mg, } 1 \text { infusion; } \\
\text { APD; } 8 \text { weeks }\end{array}$ & $\begin{array}{l}\text { - The severity of positive symptoms was improved. } \\
\text { - A positive correlation between the high-sensitive CRP } \\
\text { levels and positive symptom scores of the PANSS was } \\
\text { shown. }\end{array}$ \\
\hline
\end{tabular}

SCZ, schizophrenia; APD, antipsychotic drugs; PANSS, positive and negative syndrome scale; TOC, tocilizumab; PL, placebo; SZA, schizoaffective disorder; CNK, canakinumab; CRP, c-reactive protein.

cognitive deficits, but there were no beneficial effects on the PANSS scores and social functioning.

Pregnenolone, which acts as a neurosteroid, modulates synaptic function, such as NMDA and GABA functions [106] and also may promote neuroprotection by repairing myelin [107]. Cho et al. [101] reported that in 4 trials conducted from 2009 to 2014, total scores of the PANSS showed greater improvement in pregnenolone adjunction groups than control groups, but positive and negative scores did not. Estrogens are also considered as neuroprotective steroids. They exert anti-inflammatory properties by reducing proinflammatory cytokines and oxidative stress [108]. Estrogens also modulate many neurotransmitter mechanisms in the brain, thus estrogens can be associated with psychiatric disorders $[109,110]$. Cho et al. [101] assessed 8 trials since 2001 on estrogen adjunctive therapy and reported that the total, positive, and negative scores of the PANSS were reduced. Furthermore, SERMs such as raloxifene reduce proinflammatory cytokines of glial cells, such as IL-6 and interferon (IFN)- $\gamma$ [111]. Cho et al. [101] reported that in 9 trials investigating raloxifene adjunctive therapy, raloxifene significantly decreased the total and positive scores of the PANSS.

In summary, several therapeutic trials using anti-inflammatory agents as adjuvants to antipsychotic drugs in treating schizophrenia have shown promising results. Altogether, Cho et al. [101] comprehensively analyzed 62 trials comprising 2,914 patients that investigated the use of the 10 medicines mentioned above (aspirin, celecoxib, NAC, minocycline, omega-3 fatty acids, davunetide, EPO, pregnenolone, estrogens, and SERMs) as adjuvant therapy. Their meta-analysis showed decrease in overall scores of the PANSS and improvement in general functioning by all of the medicines and cognition improvement in the minocycline and pregnenolone trials. Cho et al. [101] also showed no significant differences in side effects between the adjuvant therapy and control groups. Likewise, Shen et al. [97] comprehensively showed beneficial effects of statins on positive and negative symptoms in 6 trials. Considering the mixed and negative results of other trials, further studies to determine effective and safe strategies for the adjunctive use of anti-inflammatory agents in patients with schizophrenia are warranted.

\section{CLINICAL EVIDENCE FOR THE THERAPEUTIC EFFECTS OF BIOLOGICAL AGENTS MODULATING INFLAMMATORY PROCESSES ON SCHIZOPHRENIA}

The results of clinical trials on the use of biological agents in the treatment of schizophrenia are summarized in Table 2. As neuroinflammation is considered to be involved in the pathophysiology of schizophrenia, anti-in- 
flammatory treatment strategies along with immune-modulating trials have been conducted. The main mechanism of conventional anti-inflammatory agents such as nonsteroidal anti-inflammatory drugs is the inhibition of the COX pathway of inflammation at the systematic level [112]. Alternatively, biological agents designed to target specific physiological processes could be more useful to modulate neuroinflammation involved in the pathophysiology of schizophrenia.

\section{Interferon- $\gamma-\mathbf{1 b}$}

The pro-inflammatory cytokine IFN- $\gamma$ plays a pivotal role in modulating immune and inflammatory responses [113]. Based on previous findings of the reduced type 1 and increased type 2 immunity in patients with schizophrenia [114], Grüber et al. [115] administered recombinant human IFN- $\gamma-1 \mathrm{~b}$ as an adjuvant to antipsychotic treatment to two patients with treatment-resistant schizophrenia. The effect of IFN- $\gamma-1$ b on stimulating the type 1 immune response showed preliminary but encouraging results in reducing clinical symptoms of schizophrenia. After approximately 1.5 months of treatment with IFN- $\gamma-1 \mathrm{~b}$ of $1.5 \mathrm{ml} /$ week, the total PANSS score of both patients had decreased. Although no significant adverse events were noted in this study, IFN- $\gamma$ treatment requires careful monitoring of side effects such as unwanted immune reactions.

\section{Monoclonal antibodies}

In the last few years, monoclonal antibodies have been used for treatment in a variety of diseases. With the pathophysiology of psychiatric disorders now becoming clearer, treatments using monoclonal antibodies that target specific cytokines have also been tried, including for schizophrenia. Some recent studies showed that antipsychotic therapies with monoclonal antibodies targeting cytokines related to neuroinflammation were effective strategies for schizophrenia.

Tocilizumab, which is usually used to treat rheumatoid arthritis, prevents inflammation by inhibiting IL-6 receptor. IL-6 may be related to hippocampal volume loss and cognitive deficits [116]. Miller et al. [116] conducted a small-sized pilot study of tocilizumab adjuvant therapy for schizophrenia. Two infusions of $4 \mathrm{mg} / \mathrm{kg}$ tocilizumab were administered for 8 weeks, but there were no significant changes observed and no adverse effects.
However, in a recent, larger-size RCT [117], the negative symptom scores of the PANSS were significantly decreased. In this study, higher doses $(8 \mathrm{mg} / \mathrm{kg}$, which was decreased as necessary for tolerability) were administered than in previous studies. However, adverse events were developed in the tocilizumab group, such as nausea, fatigue, neutrophil count decrease, and elevation in liver function test.

Canakinumab, an IL-1 $\beta$ blocking drug, was also used as an adjunct to antipsychotics for 8 weeks in a clinical study of patients with chronic schizophrenia [118]. In this study, only one infusion (150 mg) was administered to patients, and substantial decreases in the positive subscale scores of the PANSS and the high-sensitivity CRP levels were observed. No adverse events were reported.

Clinical trials are still ongoing, with some of them investigating the use in schizophrenia of monoclonal antibody therapies whose effects have been demonstrated in other neuropsychiatric disorders. Natalizumab is a multiple sclerosis drug that regulates neuroinflammation by inhibiting $\alpha 4$-integrin. A randomized controlled trial investigating the response to natalizumab in first psychotic episode patients is being conducted (NCT03093064). Fingolimod is another drug treating multiple sclerosis that is also being investigated in patients with schizophrenia (NCT01779700). Although not a monoclonal antibody, this drug is an immunomodulator acting on sphingosine-1-phosphate receptor. Similarly, Siltuximab, an anti-IL-6 chimeric monoclonal antibody used for Castleman disease, is currently being investigated for treating schizophrenia (NCT02796859).

\section{Mesenchymal stem cells}

In addition to their capacity for tissue regeneration, mesenchymal stem cells (MSCs) have an immune-modulating effect by producing anti-inflammatory cytokines, such as PGE-2, IL-10, and TGF- $\beta[119,120]$. MSCs migrate to injury sites, where they inhibit inflammation and activate restorative mechanisms [121-125].

Many recent studies have investigated the potential therapeutic effects of MSCs in brain disorders, particularly neurodegenerative diseases $[126,127]$. An inflammatory environment and immune deregulation are also considered to lead to the development of autism, which possesses many characteristics similar to schizophrenia. Ichim et al. [128] proposed mesenchymal stem cell ther- 
apy for autism, and research that is yet to be published gives an early indication that the use of MSCs in neurological disorders could be effective. In schizophrenia, mesenchymal stem cell therapy also has huge potential; many groups are now investigating this therapy to better understand the pathophysiology of schizophrenia, regardless of the therapy's outcome.

In summary, similarly to anti-inflammatory chemical agents, several biological agents have recently been investigated for adjuvant schizophrenia therapy. While the research field remains in its infancy, the results of several trials have shown the effects of adjunction of these drugs, especially monoclonal antibodies. Moreover, the effects of mesenchymal stem cells on neurological disorders and their immune-modulating properties suggest that MSCs could be effective in adjunctive schizophrenia therapy.

\section{DISCUSSION}

Various antipsychotics are being developed and several trials have been conducted to treat schizophrenia spectrum disorders. However, schizophrenia patients are currently only being treated with antipsychotics. The findings described in this review are encouraging, as they suggest that anti-inflammatory drugs may relieve psychotic symptoms and treat cognitive deficits. Moreover, the fact that the drugs used as adjuvant therapies in trials produced no notable adverse effects supports their application in the clinic. Because biological agents can inhibit specific cytokines, they also hold the promise to be effective in treating resistant, clinically well-defined patients. With the promising results recently presented by clinical trials using biological agents for neuropsychiatric disorders, successful drug repurposing and target finding for schizophrenia will likely increase.

However, as of now, there are still some limitations to the clinical application of anti-inflammatory drugs and adjuvant therapies. Due to small sample sizes in previous studies and a lack of data, more and larger studies are needed to establish anti-inflammatory adjunctive therapy as an effective method for schizophrenia. Adequate dosages of adjunctive drugs are also yet to be determined. To this end, studies about not only the effects of anti-inflammatory adjunctive drugs, but also the interactions between adjunctive drugs and antipsychotics should be conducted. Moreover, adjuvant drugs can interact with

antipsychotics and induce unexpected adverse effects that need to be monitored. Finally, cost is an important limiting factor for the potential application of biological agents as adjunctive therapy in the future.

In conclusion, although there are several limiting factors, many clinical trials have presented promising results highlighting the therapeutic potential of anti-inflammatory approaches to alleviate symptoms of schizophrenia. These efforts not only pave the way for the development of effective treatments for schizophrenia but also provide valuable insights into the etiology of a complex disorder.

\section{- Acknowledgments}

This work was supported by the Bio and Medical Technology Development Program of the National Research Foundation (NRF) funded by the Ministry of Science and ICT, Republic of Korea (Grant No. NRF-2016M3A9E8941670) and the Research Competency Milestone Program (RECOMP) of CHA University School of Medicine, Republic of Korea.

\section{- Conflicts of Interest}

No potential conflict of interest relevant to this article was reported.

\section{Author Contributions}

Conceptualization: Jonghee Hong, Minji Bang. Data review, interpretation, and manuscript preparation: Jonghee Hong, Minji Bang. Writing-original draft: Jonghee Hong. Writing-review \& editing: Jonghee Hong, Minji Bang. Funding: Minji Bang. Supervision: Minji Bang.

\section{- ORCID}

Jonghee Hong Minji Bang

\section{REFERENCES}

1. Charlson FJ, Ferrari AJ, Santomauro DF, Diminic S, Stockings E, Scott JG, et al. Global epidemiology and burden of schizophrenia: findings from the global burden of disease study 2016. Schizophr Bull 2018:44:1195-1203.

2. Millier A, Schmidt U, Angermeyer MC, Chauhan D, Murthy $\mathrm{V}$, Toumi $\mathrm{M}$, et al. Humanistic burden in schizophrenia: a literature review. J PSychiatr Res 2014;54:85-93.

3. Howes OD, Kapur S. The dopamine hypothesis of schizophrenia: version III--the final common pathway. Schizophr 
Bull 2009;35:549-562.

4. Miyamoto S, Duncan GE, Marx CE, Lieberman JA. Treatments for schizophrenia: a critical review of pharmacology and mechanisms of action of antipsychotic drugs. Mol Psychiatry 2005; 10:79-104.

5. Foussias G, Remington G. Antipsychotics and schizophrenia: from efficacy and effectiveness to clinical decision-making. Can J Psychiatry 2010;55:117-125.

6. Dold M, Samara MT, Li C, Tardy M, Leucht S. Haloperidol versus first-generation antipsychotics for the treatment of schizophrenia and other psychotic disorders. Cochrane Database Syst Rev 2015;1:CD009831.

7. Hirsch L, Yang J, Bresee L, Jette N, Patten S, Pringsheim T. Second-generation antipsychotics and metabolic side effects: a systematic review of population-based studies. Drug Saf 2017:40:771-781.

8. Brown AS, Derkits EJ. Prenatal infection and schizophrenia: a review of epidemiologic and translational studies. Am J Psychiatry 2010;167:261-280.

9. Khandaker GM, Cousins L, Deakin J, Lennox BR, Yolken R, Jones PB. Inflammation and immunity in schizophrenia: implications for pathophysiology and treatment. Lancet Psychiatry 2015;2:258-270.

10. Boksa P. Effects of prenatal infection on brain development and behavior: a review of findings from animal models. Brain Behav Immun 2010;24:881-897.

11. Meyer U. Developmental neuroinflammation and schizophrenia. Prog Neuropsychopharmacol Biol Psychiatry 2013; 42:20-34.

12. Tenn CC, Kapur S, Fletcher PJ. Sensitization to amphetamine, but not phencyclidine, disrupts prepulse inhibition and latent inhibition. Psychopharmacology (Berl) 2005; 180:366-376.

13. Romero E, Ali C, Molina-Holgado E, Castellano B, Guaza C, Borrell J. Neurobehavioral and immunological consequences of prenatal immune activation in rats. Influence of antipsychotics. Neuropsychopharmacology 2007;32:17911804.

14. Romero E, Guaza C, Castellano B, Borrell J. Ontogeny of sensorimotor gating and immune impairment induced by prenatal immune challenge in rats: implications for the etiopathology of schizophrenia. Mol Psychiatry 2010;15:372-383.

15. Shi L, Fatemi SH, Sidwell RW, Patterson PH. Maternal influenza infection causes marked behavioral and pharmacological changes in the offspring. I Neurosci 2003;23:297302.

16. Zuckerman L, Weiner I. Maternal immune activation leads to behavioral and pharmacological changes in the adult offspring. J Psychiatr Res 2005;39:311-323.

17. Bakos J, Duncko R, Makatsori A, Pirnik Z, Kiss A, Jezova D. Prenatal immune challenge affects growth, behavior, and brain dopamine in offspring. Ann N Y Acad Sci 2004; 1018:281-287.
18. Cui K, Ashdown H, Luheshi GN, Boksa P. Effects of prenatal immune activation on hippocampal neurogenesis in the rat. Schizophr Res 2009; 113:288-297.

19. Fatemi SH, Reutiman TJ, Folsom TD, Huang H, Oishi K, Mori $\mathrm{S}$, et al. Maternal infection leads to abnormal gene regulation and brain atrophy in mouse offspring: implications for genesis of neurodevelopmental disorders. Schizophr Res 2008; 99:56-70.

20. Ling Z, Zhu Y, Tong CW, Snyder JA, Lipton JW, Carvey PM. Progressive dopamine neuron loss following supra-nigral lipopolysaccharide (LPS) infusion into rats exposed to LPS prenatally. Exp Neurol 2006;199:499-512.

21. Wang S, Yan JY, Lo YK, Carvey PM, Ling Z. Dopaminergic and serotoninergic deficiencies in young adult rats prenatally exposed to the bacterial lipopolysaccharide. Brain Res 2009; 1265:196-204.

22. Brown AS. Exposure to prenatal infection and risk of schizophrenia. Front Psychiatry 2011;2:63.

23. Jonakait GM. The effects of maternal inflammation on neuronal development: possible mechanisms. Int J Dev Neurosci 2007:25:415-425.

24. Patterson PH. Immune involvement in schizophrenia and autism: etiology, pathology and animal models. Behav Brain Res 2009;204:313-321.

25. Cai Z, Pan ZL, Pang Y, Evans OB, Rhodes PG. Cytokine induction in fetal rat brains and brain injury in neonatal rats after maternal lipopolysaccharide administration. Pediatr Res 2000:47:64-72.

26. Gayle DA, Beloosesky R, Desai M, Amidi F, Nuñez SE, Ross MG. Maternal LPS induces cytokines in the amniotic fluid and corticotropin releasing hormone in the fetal rat brain. Am I Physiol Regul Integr Comp Physiol 2004;286: R1024-R1029.

27. Gilmore JH, Jarskog LF, Vadlamudi S. Maternal poly I:C exposure during pregnancy regulates TNF alpha, BDNF, and NGF expression in neonatal brain and the maternal-fetal unit of the rat. I Neuroimmunol 2005;159:106-112.

28. Urakubo A, Jarskog LF, Lieberman JA, Gilmore JH. Prenatal exposure to maternal infection alters cytokine expression in the placenta, amniotic fluid, and fetal brain. Schizophr Res 2001;47:27-36.

29. Samuelsson AM, Jennische E, Hansson HA, Holmäng A. Prenatal exposure to interleukin-6 results in inflammatory neurodegeneration in hippocampus with NMDA/GABA(A) dysregulation and impaired spatial learning. Am J Physiol Regul Integr Comp Physiol 2006;290:R1345-R1356.

30. Smith SE, Li J, Garbett K, Mirnics K, Patterson PH. Maternal immune activation alters fetal brain development through interleukin-6. J Neurosci 2007;27:10695-10702.

31. Allswede DM, Buka SL, Yolken RH, Torrey EF, Cannon TD. Elevated maternal cytokine levels at birth and risk for psychosis in adult offspring. Schizophr Res 2016;172:41-45.

32. Buka SL, Tsuang MT, Torrey EF, Klebanoff MA, Wagner RL, 
Yolken RH. Maternal cytokine levels during pregnancy and adult psychosis. Brain Behav Immun 2001;15:411-420.

33. Brown AS, Hooton J, Schaefer CA, Zhang H, Petkova E, Babulas $\mathrm{V}$, et al. Elevated maternal interleukin-8 levels and risk of schizophrenia in adult offspring. Am J Psychiatry 2004;161:889-895.

34. Brown AS, Cohen P, Harkavy-Friedman J, Babulas V, Malaspina D, Gorman JM, et al. A.E. Bennett Research Award. Prenatal rubella, premorbid abnormalities, and adult schizophrenia. Biol Psychiatry 2001;49:473-486.

35. Brown AS, Vinogradov S, Kremen WS, Poole JH, Bao Y, Kern $\mathrm{D}$, et al. Association of maternal genital and reproductive infections with verbal memory and motor deficits in adult schizophrenia. Psychiatry Res 2011;188:179-186.

36. Ellman LM, Yolken RH, Buka SL, Torrey EF, Cannon TD. Cognitive functioning prior to the onset of psychosis: the role of fetal exposure to serologically determined influenza infection. Biol Psychiatry 2009; 65:1040-1047.

37. Brown AS, Deicken RF, Vinogradov S, Kremen WS, Poole $\mathrm{JH}$, Penner JD, et al. Prenatal infection and cavum septum pellucidum in adult schizophrenia. Schizophr Res 2009; 108:285-287.

38. Ellman LM, Deicken RF, Vinogradov S, Kremen WS, Poole $\mathrm{JH}$, Kern DM, et al. Structural brain alterations in schizophrenia following fetal exposure to the inflammatory cytokine interleukin-8. Schizophr Res 2010;121:46-54.

39. Miller BJ, Buckley P, Seabolt W, Mellor A, Kirkpatrick B. Meta-analysis of cytokine alterations in schizophrenia: clinical status and antipsychotic effects. Biol Psychiatry 2011;70:663-671.

40. Bolu A, Aydın MS, Akgün A, Coşkun A, Garip B, Öznur T, et al. Serum levels of high sensitivity c-reactive protein in drug-naïve first-episode psychosis and acute exacerbation of schizophrenia. Clin Psychopharmacol Neurosci 2019;17: 244-249.

41. Monji A, Kato TA, Mizoguchi Y, Horikawa H, Seki Y, Kasai $\mathrm{M}$, et al. Neuroinflammation in schizophrenia especially focused on the role of microglia. Prog Neuropsychopharmacol Biol Psychiatry 2013;42:115-121.

42. Furukawa $\mathrm{H}$, del Rey A, Monge-Arditi G, Besedovsky HO. Interleukin-1, but not stress, stimulates g/ucocorticoid output during early postnatal life in mice. Ann NY Acad Sci 1998;840:117-122.

43. Müller N, Weidinger E, Leitner B, Schwarz MJ. The role of inflammation in schizophrenia. Front Neurosci 2015;9:372.

44. Nair A, Bonneau RH. Stress-induced elevation of glucocorticoids increases microglia proliferation through NMDA receptor activation. J Neuroimmunol 2006;171:72-85.

45. Sparkman NL, Johnson RW. Neuroinflammation associated with aging sensitizes the brain to the effects of infection or stress. Neuroimmunomodulation 2008;15:323-330.

46. Frank MG, Baratta MV, Sprunger DB, Watkins LR, Maier SF. Microglia serve as a neuroimmune substrate for stress-in- duced potentiation of CNS pro-inflammatory cytokine responses. Brain Behav Immun 2007;21:47-59.

47. Zhou D, Kusnecov AW, Shurin MR, DePaoli M, Rabin BS. Exposure to physical and psychological stressors elevates plasma interleukin 6: relationship to the activation of hypothalamic-pituitary-adrenal axis. Endocrinology 1993;133: 2523-2530.

48. Howes OD, McCutcheon R. Inflammation and the neural di athesis-stress hypothesis of schizophrenia: a reconceptualization. Trans/ Psychiatry 2017;7:e1024.

49. Zalcman S, Murray L, Dyck DG, Greenberg AH, Nance DM. Interleukin-2 and -6 induce behavioral-activating effects in mice. Brain Res 1998;811:111-121.

50. Zalcman S, Savina I, Wise RA. Interleukin-6 increases sensitivity to the locomotor-stimulating effects of amphetamine in rats. Brain Res 1999;847:276-283.

51. Behrens MM, Ali SS, Dugan LL. Interleukin-6 mediates the increase in NADPH-oxidase in the ketamine model of schizophrenia. J Neurosci 2008;28:13957-13966.

52. Block ML, Hong JS. Microglia and inflammation-mediated neurodegeneration: multiple triggers with a common mechanism. Prog Neurobiol 2005;76:77-98.

53. Parrott JM, O'Connor JC. Kynurenine 3-monooxygenase: an influential mediator of neuropathology. Front Psychiatry 2015;6:116.

54. Stone TW, Darlington LG. Endogenous kynurenines as targets for drug discovery and development. Nat Rev Drug Discov 2002; 1:609-620.

55. laccarino HF, Suckow RF, Xie S, Bucci DJ. The effect of transient increases in kynurenic acid and quinolinic acid levels early in life on behavior in adulthood: Implications for schizophrenia. Schizophr Res 2013;150:392-397.

56. Larsson MK, Faka A, Bhat M, Imbeault S, Goiny M, Orhan F, et al. Repeated LPS injection induces distinct changes in the kynurenine pathway in mice. Neurochem Res 2016;41: 2243-2255.

57. Pérez-Neri I, Ramírez-Bermúdez J, Montes S, Ríos C. Possible mechanisms of neurodegeneration in schizophrenia. Neurochem Res 2006;31:1279-1294.

58. Trépanier MO, Hopperton KE, Mizrahi R, Mechawar N, Bazinet RP. Postmortem evidence of cerebral inflammation in schizophrenia: a systematic review. Mol Psychiatry 2016; 21:1009-1026.

59. van Kesteren CF, Gremmels $\mathrm{H}$, de Witte LD, Hol EM, Van Gool AR, Falkai PG, et al. Immune involvement in the pathogenesis of schizophrenia: a meta-analysis on postmortem brain studies. Trans/ Psychiatry 2017;7:e1075.

60. Doorduin J, de Vries EF, Willemsen AT, de Groot JC, Dierckx RA, Klein HC. Neuroinflammation in schizophrenia-related psychosis: a PET study. J Nucl Med 2009;50:1801-1807.

61. van Berckel $B N$, Bossong MG, Boellaard R, Kloet R, Schuitemaker $\mathrm{A}$, Caspers $\mathrm{E}$, et al. Microglia activation in recent-onset schizophrenia: a quantitative (R)-[11C]PK11195 
positron emission tomography study. Biol Psychiatry 2008; 64:820-822.

62. Bloomfield PS, Selvaraj S, Veronese M, Rizzo G, Bertoldo A, Owen DR, et al. Microglial activity in people at ultra high risk of psychosis and in schizophrenia: an [(11)C]PBR28 PET brain imaging study. Am J Psychiatry 2016;173:44-52.

63. Millan MJ, Andrieux A, Bartzokis G, Cadenhead K, Dazzan P, Fusar-Poli P, et al. Altering the course of schizophrenia: progress and perspectives. Nat Rev Drug Discov 2016;15: 485-515.

64. El-Sayed El-Sisi A, Sokkar SS, El-Sayed El-Sayad M, Sayed Ramadan E, Osman EY. Celecoxib and omega-3 fatty acids alone and in combination with risperidone affect the behavior and brain biochemistry in amphetamine-induced model of schizophrenia. Biomed Pharmacother 2016;82:425-431.

65. Brenhouse HC, Andersen SL. Nonsteroidal anti-inflammatory treatment prevents delayed effects of early life stress in rats. Biol Psychiatry 2011;70:434-440.

66. Klausberger T, Marton LF, O'Neill J, Huck JH, Dalezios Y, Fuentealba $\mathrm{P}$, et al. Complementary roles of cholecystokininand parvalbumin-expressing GABAergic neurons in hippocampal network oscillations. J Neurosci 2005;25:97829793.

67. Lewis DA, Hashimoto T, Volk DW. Cortical inhibitory neurons and schizophrenia. Nat Rev Neurosci 2005; 6:312-324.

68. Rotaru DC, Lewis DA, Gonzalez-Burgos G. The role of g/utamatergic inputs onto parvalbumin-positive interneurons: relevance for schizophrenia. Rev Neurosci 2012;23:97-109.

69. Moher D, Liberati A, Tetzlaff J, Altman DG; PRISMA Group. Preferred reporting items for systematic reviews and meta-analyses: the PRISMA statement. Ann Intern Med 2009;151:264-269, W264.

70. Corsello SM, Bittker JA, Liu Z, Gould J, McCarren P, Hirschman JE, et al. The Drug Repurposing Hub: a next-generation drug library and information resource. Nat Med 2017;23:405-408.

71. Laan W, Grobbee DE, Selten JP, Heijnen CJ, Kahn RS, Burger $\mathrm{H}$. Adjuvant aspirin therapy reduces symptoms of schizophrenia spectrum disorders: results from a randomized, double-blind, placebo-controlled trial. J Clin Psychiatry 2010; 71:520-527.

72. Attari A, Mojdeh A, Khalifeh Soltani FAS, Najarzadegan MR. Aspirin inclusion in antipsychotic treatment on severity of symptoms in schizophrenia: a randimized clinical trial. Iran J Psychiatry Behav Sci 2017;11:e5848.

73. Müller N, Riedel M, Scheppach C, Brandstätter B, Sokullu S, Krampe K, et al. Beneficial antipsychotic effects of celecoxib add-on therapy compared to risperidone alone in schizophrenia. Am J Psychiatry 2002;159:1029-1034.

74. Akhondzadeh S, Tabatabaee M, Amini H, Ahmadi Abhari SA, Abbasi SH, Behnam B. Celecoxib as adjunctive therapy in schizophrenia: a double-blind, randomized and placebo-controlled trial. Schizophr Res 2007;90:179-185.
75. Rapaport MH, Delrahim KK, Bresee CJ, Maddux RE, Ahmadpour O, Dolnak D. Celecoxib augmentation of continuously ill patients with schizophrenia. Biol Psychiatry 2005; 57:1594-1596.

76. Müller N, Krause D, Dehning S, Musil R, Schennach-Wolff $\mathrm{R}$, Obermeier $\mathrm{M}$, et al. Celecoxib treatment in an early stage of schizophrenia: results of a randomized, double-blind, placebo-controlled trial of celecoxib augmentation of amisulpride treatment. Schizophr Res 2010;121:118-124.

77. Chen G, Shi J, Hu Z, Hang C. Inhibitory effect on cerebral inflammatory response following traumatic brain injury in rats: a potential neuroprotective mechanism of $\mathrm{N}$-acetylcysteine. Mediators Inflamm 2008;2008:716458.

78. Csontos C, Rezman B, Foldi V, Bogar L, Drenkovics L, Röth $\mathrm{E}$, et al. Effect of $\mathrm{N}$-acetylcysteine treatment on oxidative stress and inflammation after severe burn. Burns 2012; 38:428-437.

79. Janáky R, Varga V, Saransaari P, Oja SS. Glutathione modulates the $\mathrm{N}$-methyl-D-aspartate receptor-activated calcium influx into cultured rat cerebellar granule cells. Neurosci Lett 1993;156:153-157.

80. Keller WR, Kum LM, Wehring HJ, Koola MM, Buchanan RW, Kelly DL. A review of anti-inflammatory agents for symptoms of schizophrenia. J Psychopharmacol 2013;27: 337-342.

81. Farokhnia M, Azarkolah A, Adinehfar F, Khodaie-Ardakani MR, Hosseini SM, Yekehtaz $\mathrm{H}$, et al. N-acetylcysteine as an adjunct to risperidone for treatment of negative symptoms in patients with chronic schizophrenia: a randomized, double-blind, placebo-controlled study. Clin Neuropharmacol 2013;36:185-192.

82. Kerksick C, Willoughby D. The antioxidant role of glutathione and $\mathrm{N}$-acetyl-cysteine supplements and exercise-induced oxidative stress. J Int Soc Sports Nutr 2005; 2:38-44.

83. Do KQ, Cabungcal JH, Frank A, Steullet P, Cuenod M. Redox dysregulation, neurodevelopment, and schizophrenia. Curr Opin Neurobiol 2009;19:220-230.

84. Hashimoto K. Targeting of NMDA receptors in new treatments for schizophrenia. Expert Opin Ther Targets 2014;18: 1049-1063.

85. Berk M, Copolov D, Dean O, Lu K, Jeavons S, Schapkaitz I, et al. N-acetyl cysteine as a g/utathione precursor for schizophrenia--a double-blind, randomized, placebo-controlled trial. Biol Psychiatry 2008;64:361-368.

86. Wehring HJ, Elsobky T, McEvoy JP, Vyas G, Richardson CM, McMahon RP, et al. Adjunctive minocycline in clozapine-treated patients with schizophrenia: analyzing the effects of minocycline on clozapine plasma levels. Psychiatr $Q$ 2017;89:73-80.

87. Xiang YQ, Zheng W, Wang SB, Yang XH, Cai DB, Ng CH, et al. Adjunctive minocycline for schizophrenia: a meta-analysis of randomized controlled trials. Eur Neuropsychopharmacol 
2017;27:8-18.

88. Asanuma Y, Oeser A, Stanley E, Bailey DG, Shintani A, Stein $\mathrm{CM}$. Effects of C-reactive protein and homocysteine on cytokine production: modulation by pravastatin. Arch Drug Inf 2008;1:14-22.

89. Chen SF, Hung TH, Chen CC, Lin $\mathrm{KH}$, Huang $\mathrm{YN}$, Tsai HC, et al. Lovastatin improves histological and functional outcomes and reduces inflammation after experimental traumatic brain injury. Life Sci 2007;81:288-298.

90. Rosendo AB, Lima LO, Dal-Pizzol F, Almeida S. Lipid and C-reactive protein levels, cardiovascular disease risk factors and simvastatin treatment in Brazilian individuals. Inflammation 2010;33:244-250.

91. Zhang J, Yang Z, Xie L, Xu L, Xu D, Liu X. Statins, autophagy and cancer metastasis. Int I Biochem Cell Biol 2013:45: 745-752.

92. Wang Q, Zengin A, Deng C, Li Y, Newell KA, Yang GY, et al. High dose of simvastatin induces hyperlocomotive and anxiolytic-like activities: the association with the up-regulation of NMDA receptor binding in the rat brain. Exp Neurol 2009;216:132-138.

93. Vevera J, Fisar Z, Kvasnicka T, Zdenek H, Stárková L, Ceska $\mathrm{R}$, et al. Cholesterol-lowering therapy evokes time-limited changes in serotonergic transmission. Psychiatry Res 2005; 133:197-203.

94. Vevera J, Valeš K, Fišar Z, Hroudová J, Singh N, Stuchlík A, et al. The effect of prolonged simvastatin application on serotonin uptake, membrane microviscosity and behavioral changes in the animal model. Physiol Behav 2016; 158:112-120.

95. Wang Q, Ting WL, Yang H, Wong PT. High doses of simvastatin upregulate dopamine $D 1$ and $D 2$ receptor expression in the rat prefrontal cortex: possible involvement of endothelial nitric oxide synthase. Br J Pharmacol 2005; 144:933-939.

96. Wang Q, Zengin A, Ying W, Newell KA, Wang P, Yeo W, et al. Chronic treatment with simvastatin upregulates muscarinic M1/4 receptor binding in the rat brain. Neuroscience 2008;154:1100-1106.

97. Shen H, Li R, Yan R, Zhou X, Feng X, Zhao M, et al. Adjunctive therapy with statins in schizophrenia patients: a meta-analysis and implications. Psychiatry Res 2018; 262:84-93.

98. Bazan NG. Omega-3 fatty acids, pro-inflammatory signaling and neuroprotection. Curr Opin Clin Nutr Metab Care 2007; 10:136-141.

99. Singer P, Shapiro H, Theilla M, Anbar R, Singer J, Cohen J. Anti-inflammatory properties of omega-3 fatty acids in critical illness: novel mechanisms and an integrative perspective. Intensive Care Med 2008;34:1580-1592.

100. Chalon S. Omega-3 fatty acids and monoamine neurotransmission. Prostaglandins Leukot Essent Fatty Acids 2006; 75:259-269.

101. Cho M, Lee TY, Kwak YB, Yoon YB, Kim M, Kwon JS.
Adjunctive use of anti-inflammatory drugs for schizophrenia: a meta-analytic investigation of randomized controlled trials. Aust N ZJ Psychiatry 2019;53:742-759.

102. Javitt DC, Buchanan RW, Keefe RS, Kern R, McMahon RP, Green MF, et al. Effect of the neuroprotective peptide davunetide (AL-108) on cognition and functional capacity in schizophrenia. Schizophr Res 2012;136:25-31.

103. Gozes I. NAP (davunetide) provides functional and structural neuroprotection. Curr Pharm Des 2011;17:1040-1044.

104. Sirén AL, Ehrenreich H. Erythropoietin--a novel concept for neuroprotection. Eur Arch Psychiatry Clin Neurosci 2001; 251:179-184.

105. Ehrenreich H, Hinze-Selch D, Stawicki S, Aust C, KnolleVeentjer S, Wilms S, et al. Improvement of cognitive functions in chronic schizophrenic patients by recombinant human erythropoietin. Mol Psychiatry 2007; 12:206-220.

106. Mellon SH. Neurosteroid regulation of central nervous system development. Pharmacol Ther 2007;116:107-124.

107. Koenig HL, Schumacher M, Ferzaz B, Thi AN, Ressouches A, Guennoun R, et al. Progesterone synthesis and myelin formation by Schwann cells. Science 1995;268:1500-1503.

108. Pandurangi AK, Buckley PF. Inflammation, antipsychotic drugs, and evidence for effectiveness of anti-inflammatory agents in schizophrenia. Curr Top Behav Neurosci 2019. doi: 10.1007/7854_2019_91. [Epub ahead of print]

109. Fink G, Sumner BE, Rosie R, Grace O, Quinn JP. Estrogen control of central neurotransmission: effect on mood, mental state, and memory. Cell Mol Neurobiol 1996; 16:325-344.

110. Kulkarni J, de Castella A, Fitzgerald PB, Gurvich CT, Bailey $\mathrm{M}$, Bartholomeusz $\mathrm{C}$, et al. Estrogen in severe mental illness: a potential new treatment approach. Arch Gen Psychiatry 2008:65:955-960.

111. Arevalo MA, Diz-Chaves Y, Santos-Galindo M, Bellini MJ, Garcia-Segura LM. Selective oestrogen receptor modulators decrease the inflammatory response of glial cells. J Neuroendocrinol 2012;24:183-190.

112. Peesa JP, Yalavarthi PR, Rasheed A, Mandava VBR. A perspective review on role of novel NSAID prodrugs in the management of acute inflammation. I Acute Dis 2016;5: 364-381.

113. Farrar MA, Schreiber RD. The molecular cell biology of interferon-gamma and its receptor. Annu Rev Immunol 1993; 11:571-611.

114. Müller N, Schwarz MJ. Neuroimmune-endocrine crosstalk in schizophrenia and mood disorders. Expert Rev Neurother 2006;6:1017-1038.

115. Grüber L, Bunse T, Weidinger E, Reichard H, Müller N. Adjunctive recombinant human interferon gamma-1b for treatment-resistant schizophrenia in 2 patients. J Clin Psychiatry 2014;75:1266-1267.

116. Miller BJ, Dias JK, Lemos HP, Buckley PF. An open-label, pilot trial of adjunctive tocilizumab in schizophrenia. J Clin Psychiatry 2016;77:275-276. 
117. Girgis RR, Ciarleglio A, Choo T, Haynes G, Bathon JM, Cremers S, et al. A randomized, double-blind, placebo-controlled clinical trial of tocilizumab, an interleukin-6 receptor antibody, for residual symptoms in schizophrenia. Neuropsychopharmacology 2018;43:1317-1323.

118. Weickert T, Jacomb I, Lenroot R, Lappin J, Weinberg D, Brooks W, et al. Reduction in peripheral c-reactive protein levels with canakinumab administration is related to reduced positive symptom severity in patients with schizophrenia and inflammation. Schizophr Bull 2019;45:S318.

119. Siniscalco D, Sapone A, Cirillo A, Giordano C, Maione S, Antonucci N. Autism spectrum disorders: is mesenchymal stem cell personalized therapy the future? I Biomed Biotechnol 2012;2012:480289.

120. Giuliani M, Fleury M, Vernochet A, Ketroussi F, Clay D, Azzarone $\mathrm{B}$, et al. Long-lasting inhibitory effects of fetal liver mesenchymal stem cells on T-lymphocyte proliferation. PLoS One 2011;6:e19988.

121. Beggs KJ, Lyubimov A, Borneman JN, Bartholomew A, Moseley A, Dodds R, et al. Immunologic consequences of multiple, high-dose administration of allogeneic mesenchymal stem cells to baboons. Cell Transplant 2006;15: 711-721.
122. Le Blanc K, Pittenger M. Mesenchymal stem cells: progress toward promise. Cytotherapy 2005;7:36-45.

123. Guginski G, Luiz AP, Silva MD, Massaro M, Martins DF, Chaves J, et al. Mechanisms involved in the antinociception caused by ethanolic extract obtained from the leaves of Melissa officinalis (lemon balm) in mice. Pharmacol Biochem Behav 2009;93:10-16.

124. Siniscalco D, Giordano C, Galderisi U, Luongo L, Alessio N, Di Bernardo G, et al. Intra-brain microinjection of human mesenchymal stem cells decreases allodynia in neuropathic mice. Cell Mol Life Sci 2010;67:655-669.

125. Uccelli A, Moretta L, Pistoia V. Mesenchymal stem cells in health and disease. Nat Rev Immunol 2008;8:726-736.

126. Joyce N, Annett G, Wirthlin L, Olson S, Bauer G, Nolta JA. Mesenchymal stem cells for the treatment of neurodegenerative disease. Regen Med 2010;5:933-946.

127. Sherman LS, Romagano MP, Williams SF, Rameshwar P. Mesenchymal stem cell therapies in brain disease. Semin Cell Dev Biol 2019. doi: 10.1016/J.semcdb.2019.03.003. [Epub ahead of print]

128. Ichim TE, Solano F, Glenn E, Morales F, Smith L, Zabrecky G, et al. Stem cell therapy for autism. J Trans/ Med 2007;5:30. 